Prepared in cooperation with various Federal, State, and local agencies

\title{
Floods of May and June 2008 in lowa
}

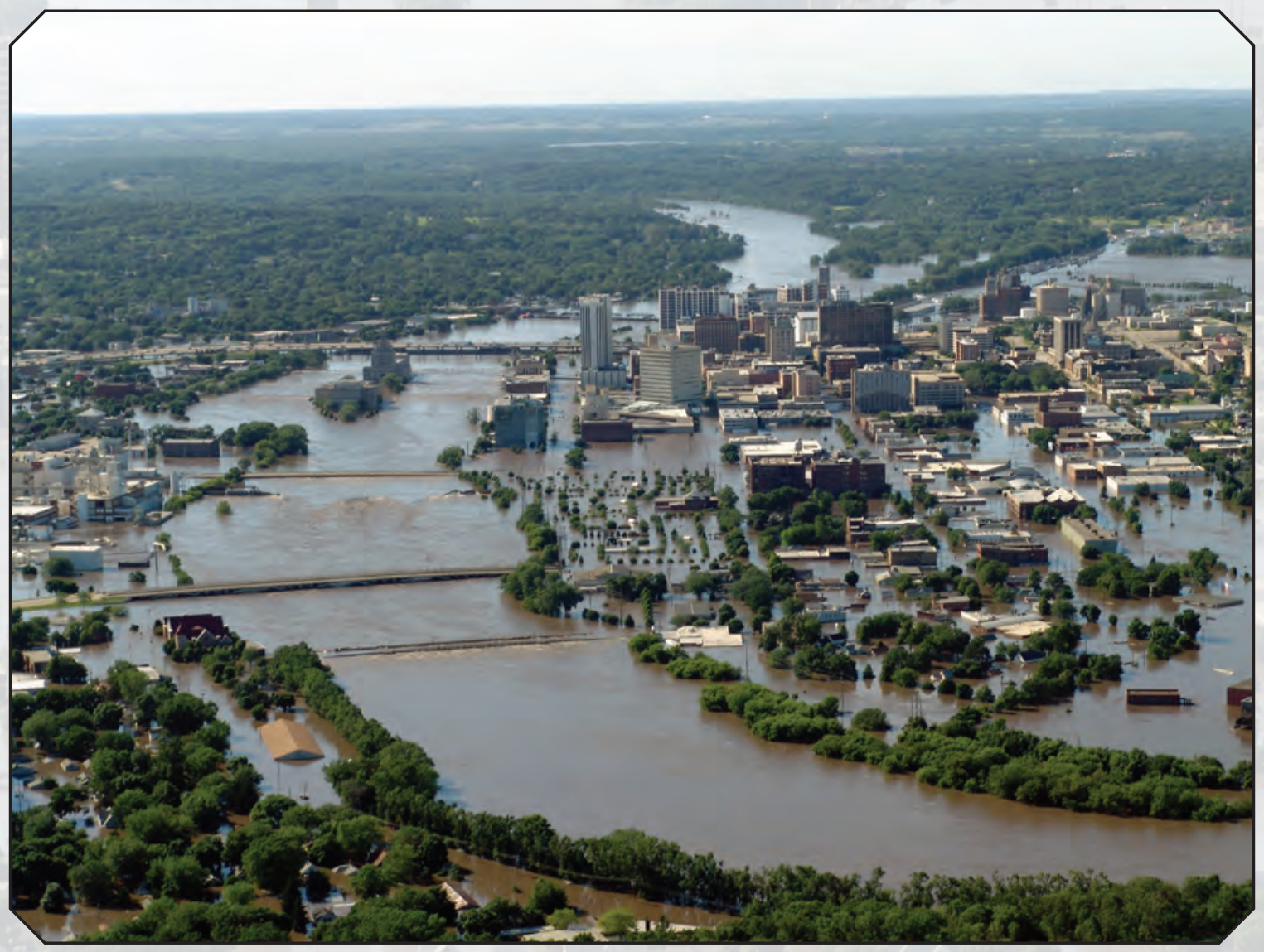

Open-File Report 2010-1096

U.S. Department of the Interior

U.S. Geological Survey 
Cover photograph. The Cedar River and urban flooding in Cedar Rapids, lowa, June 12, 2008. 


\section{Floods of May and June 2008 in lowa}

By Robert C. Buchmiller and David A. Eash

Prepared in cooperation with various Federal, State, and local agencies

Open-File Report 2010-1096

U.S. Department of the Interior

U.S. Geological Survey 


\title{
U.S. Department of the Interior \\ KEN SALAZAR, Secretary \\ U.S. Geological Survey \\ Marcia K. McNutt, Director
}

\section{U.S. Geological Survey, Reston, Virginia: 2010}

\author{
For more information on the USGS — the Federal source for science about the Earth, its natural and living resources, \\ natural hazards, and the environment, visit http://www.usgs.gov or call 1-888-ASK-USGS \\ For an overview of USGS information products, including maps, imagery, and publications, \\ visit http://www.usgs.gov/pubprod \\ To order this and other USGS information products, visit http://store.usgs.gov
}

Any use of trade, product, or firm names is for descriptive purposes only and does not imply endorsement by the U.S. Government.

Although this report is in the public domain, permission must be secured from the individual copyright owners to reproduce any copyrighted materials contained within this report.

Suggested citation:

Buchmiller, R.C., and Eash, D.A., 2010, Floods of May and June 2008 in lowa: U.S. Geological Survey Open-File Report 2010-1096, $10 \mathrm{p}$. 


\section{Contents}

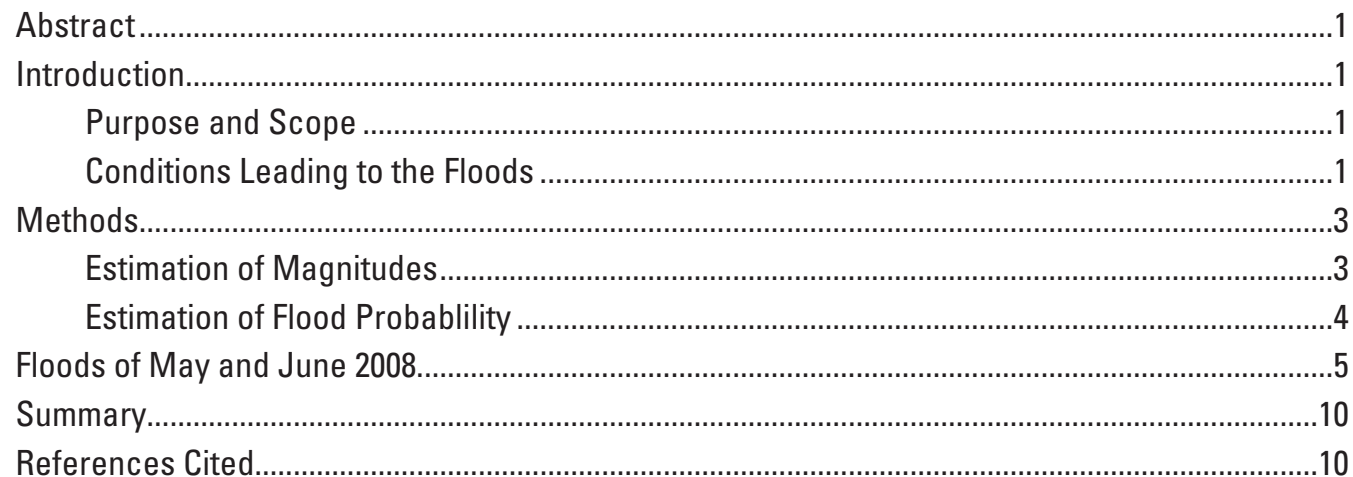

\section{Figures}

1. Map showing location of lowa streamgages with new peak discharges or where the flood probability was estimated to be 1 percent or less, May and June 2008.

2-3. Screen captures showing-

2. Statewide observed precipitation for lowa, May 2008 ..............................................

3. Statewide observed precipitation for lowa, June 2008 ...........................................

4. Graph showing historic annual peak discharges for the Cedar River at Cedar Rapids (05464500) streamgage, 1903 to 2008.

\section{Tables}

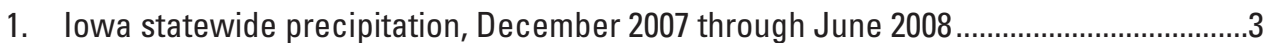

2. Flood-peak stage and discharge for selected lowa streamgages where a new peak-discharge record was recorded or where the flood probability was estimated to be 1 percent or less during May and June 2008 


\section{Conversion Factors and Datums}

Inch/Pound to SI

\begin{tabular}{lcl}
\hline \multicolumn{1}{c}{ Multiply } & By & \multicolumn{1}{c}{ To obtain } \\
\hline inch (in.) & Length & \\
foot (ft) & 2.54 & centimeter $(\mathrm{cm})$ \\
& 0.3048 & meter $(\mathrm{m})$ \\
\hline square mile $\left(\mathrm{mi}^{2}\right)$ & Area & \\
\hline & 2.590 & square kilometer $\left(\mathrm{km}^{2}\right)$ \\
\hline cubic foot per second $\left(\mathrm{ft}^{3} / \mathrm{s}\right)$ & Flow rate & cubic meter per second $\left(\mathrm{m}^{3} / \mathrm{s}\right)$ \\
\hline
\end{tabular}

Elevation or vertical coordinate information is referenced to the National Geodetic Vertical Datum of 1929 (NGVD 1929). Elevation refers to distance above or below NGVD 1929. NGVD 1929 can be converted to the North American Vertical Datum of 1988 (NAVD 88) by using the National

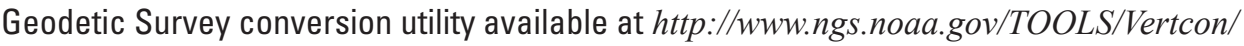
vertcon.html.

Horizontal coordinate information is referenced to the North American Datum of 1983 (NAD 83).

Water year is the 12-month period from October 1 through September 30. The water year is designated by the calendar year in which the water year ends and that includes 9 of the 12 months. Thus, the water year ending September 30, 2008, is called the "2008 water year." 


\title{
Floods of May and June 2008 in lowa
}

\author{
By Robert C. Buchmiller and David A. Eash
}

\section{Abstract}

An unusually wet winter and spring of 2007 to 2008 resulted in extremely wet antecedent conditions throughout most of Iowa. Rainfall of 5 to 15 inches was observed in eastern Iowa during May 2008, and an additional 5 to 15 inches of rain was observed throughout most of Iowa in June. Because of the severity of the May and June 2008 flooding, the U.S. Geological Survey, in cooperation with other Federal, State, and local agencies, has summarized the meteorological and hydrological conditions leading to the flooding, compiled flood-peak stages and discharges, and estimated revised flood probabilities for 62 selected streamgages.

Record peak discharges or flood probabilities of 1 percent or smaller (100-year flooding or greater) occurred at more than 60 streamgage locations, particularly in eastern Iowa. Cedar Rapids, Decorah, Des Moines, Iowa City, Mason City, and Waterloo were among the larger urban areas affected by this flooding. High water and flooding in small, headwater streams in north-central and eastern Iowa, particularly in June, combined and accumulated in large, mainstem rivers and resulted in flooding of historic proportions in the Cedar and Iowa Rivers. Previous flood-peak discharges at many locations were exceeded by substantial amounts, in some cases nearly doubling the previous record peak discharge at locations where more than 100 years of streamflow record are available.

\section{Introduction}

An unusually wet winter and spring of 2007 to 2008 resulted in extremely wet antecedent conditions throughout most of Iowa. Spring rains beginning in April 2008 caused record flooding in some areas. Rainfall was exceptionally plentiful from May through June 2008. During this time, record high discharges or flood probabilities of 1 percent or smaller (100-year flooding or greater) occurred at more than 60 streamgage locations, particularly in eastern Iowa. High water and flooding in small, headwater streams in northcentral and eastern Iowa, particularly in June, combined and accumulated in large, mainstem rivers and resulted in flooding of historic proportions in the Cedar and Iowa Rivers. Previous flood-peak discharges at many locations were exceeded by substantial amounts, in some cases nearly doubling the previous record peak discharge at locations where more than 100 years of streamflow record are available.

Because of the severity of the May and June 2008 flooding, the U.S. Geological Survey (USGS), in cooperation with other Federal, State, and local agencies, has summarized the meteorological and hydrological conditions leading to the flooding, compiled flood-peak stages and discharges, and estimated revised flood probabilities for 62 selected streamgages.

\section{Purpose and Scope}

This report presents hydrologic and flood-probability information related to the flooding that occurred in Iowa (fig. 1) during May and June 2008. Additional maximumpeak discharges occurred at several streamgages in Iowa during April, July, and September 2008, but this flooding was not widespread and was separate from the May and June flooding time frame by several weeks and is not included in this report.

Meteorologic conditions contributing to the flooding are discussed. Peak-stage and peak-discharge data are presented for 62 active continuous-record and partial-record streamgages in Iowa. Recalculated flood-probability statistics that include the 2008 flood peaks also are presented for most of the 62 streamgages.

\section{Conditions Leading to the Floods}

Antecedent conditions in Iowa prior to the spring and summer of 2008 were wet. Precipitation from December 2007 through May 2008 was the second wettest on record from 1895 to 2008 . Notably, the precipitation in eastern Iowa and southern Wisconsin was characterized by extremely wet conditions that normally occur less than 2.5 percent of the time (National Climatic Data Center, 2008). New monthly precipitation records were set across Iowa during this period. New records were set at seven sites in December, six sites in April, one site in May, eight sites in June, and one site in July. The precipitation records at all but two of the sites were greater than 100 years (Hillaker, 2008). The monthly statewide precipitation amounts and comments by the Iowa State Climatologist for December 2007 to June 2008 are tabulated in table 1. 


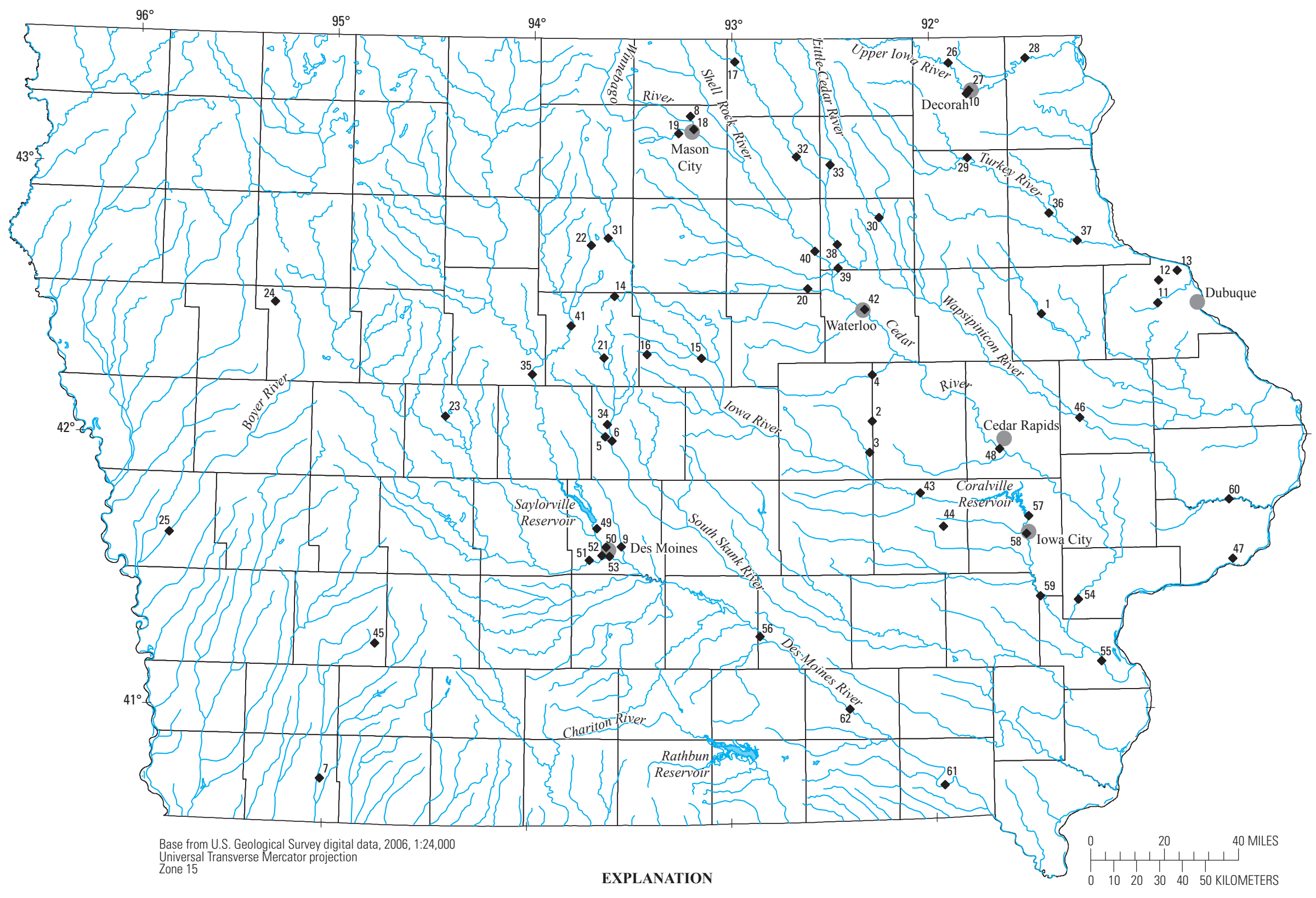

U.S. Geological Survey streamgage

Figure 1. Location of lowa streamgages with new peak discharges or where the flood probability was estimated to be 1 percent or less, May and June 2008. 
Table 1. lowa statewide precipitation, December 2007 through June 2008.

$[+$, greater than normal; -, less than normal]

\begin{tabular}{|c|c|c|c|}
\hline Date & $\begin{array}{l}\text { lowa } \\
\text { statewide } \\
\text { precipitation } \\
\text { (inches) }\end{array}$ & $\begin{array}{l}\text { Departure } \\
\text { from normal } \\
\text { precipitation } \\
\text { (inches) }\end{array}$ & $\begin{array}{l}\text { Comments by the State Climatologist } \\
\text { (Hillaker, 2008) }\end{array}$ \\
\hline January 2008 & .70 & -.25 & $\begin{array}{l}\text { "Precipitation was frequent during January but lacked the major winter storm events } \\
\text { seen in December." }\end{array}$ \\
\hline March 2008 & 1.25 & -.96 & $\begin{array}{l}\text { "Precipitation was well below normal over most of the State. The result was that snow } \\
\text { melt flooding, though widespread, did not reach severe proportions in most areas. } \\
\text { Nevertheless, frequent light precipitation events, and cooler than usual weather, kept } \\
\text { soils very soggy and made for poor driving conditions on many unpaved roadways." }\end{array}$ \\
\hline April 2008 & 5.88 & +2.55 & $\begin{array}{l}\text { "Second wettest April in } 136 \text { years of state records. Three storm systems each dropped } \\
\text { an average of over an inch of rain statewide. Major flooding followed the third, and } \\
\text { largest, storm of the series." }\end{array}$ \\
\hline June 2008 & 9.01 & +4.37 & $\begin{array}{l}\text { "Iowa endured an exceptionally wet period from May } 29 \text { through June } 12 \text { when a } \\
\text { statewide average of } 9.03 \text { inches of rain fell (normal for the period is } 2.45 \text { inches). } \\
\text { Daily statewide average rain statistics are not available very far back in time but it is } \\
\text { doubtful that a larger amount of rain has been recorded in Iowa in only } 15 \text { days." }\end{array}$ \\
\hline
\end{tabular}

Statewide observed precipitation for Iowa during May 2008 is shown on figure 2. Rainfall ranged from about 2 inches (in.) along the northern border and in south-central areas near Des Moines to more than 10 in. in northeast Iowa west of Dubuque. Rainfall in excess of 5 in. fell across much of the northern one-third of Iowa. June 2008 statewide observed precipitation for Iowa is shown on figure 3. Rainfall exceeded 5 in. across most of the State, with amounts commonly exceeding $10 \mathrm{in}$. in northeast and southwest Iowa. Some areas, particularly in southwest Iowa, received more than 15 in. of rain.

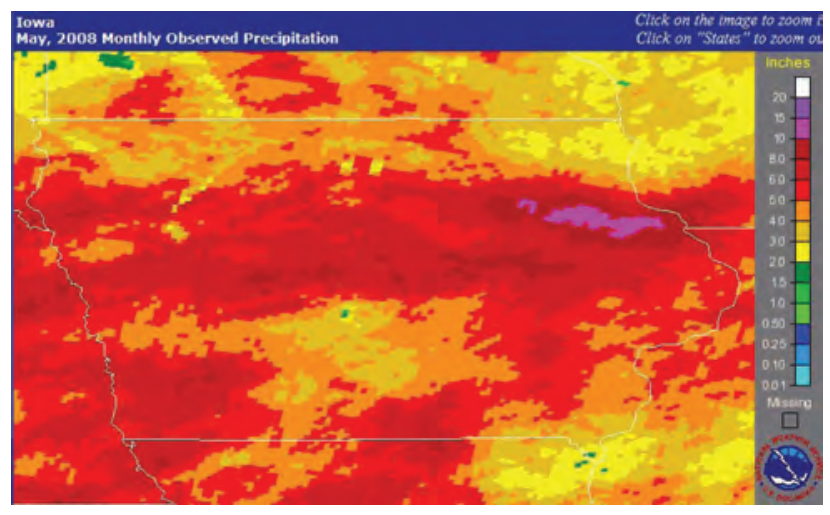

Data from the National Weather Service, 2009

Figure 2. Statewide observed precipitation for lowa, May 2008.

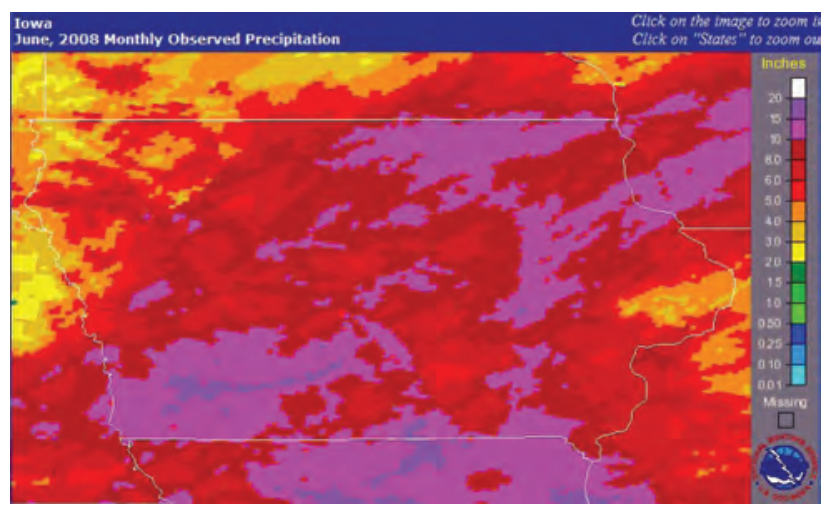

Data from the National Weather Service, 2009

Figure 3. Statewide observed precipitation for lowa, June 2008.

\section{Methods}

\section{Estimation of Magnitudes}

Peak discharges documented in this report were determined by use of the rating curve (the relation between river height and flow) for each streamgage. Rating curves at streamgages are developed by relating stage to discharge for a range of flows (Rantz and others, 1982). Discharge data points used to develop a rating are determined most commonly by direct measurement at the gage; or, if direct measurement is not possible, by indirect methods. No indirect methods were 
used for the data in this report. The rating curve is interpolated between discharge data points and can be extrapolated beyond the highest discharge data point; however, excessive extrapolation of the rating at high stages can result in large errors in discharge (Sherwood and others, 2007).

Peak-stage data were obtained either from electronic data recorders or from surveyed high-water marks where recorders or stage sensors were destroyed or malfunctioned. The rating curve was used to compute peak discharge from peak stage.

Direct discharge measurements served as data points at or near the respective flood peaks for rating-curve verification and extrapolation.

\section{Estimation of Flood Probablility}

Flood probability for a specific discharge is the probability or chance of that discharge being equaled or exceeded in any particular year. For example, a probability of 0.01 means there is a 1 percent chance of that flow magnitude being equaled or exceeded in any particular year. Stated another way, the chances are 1 in 100 that the flow will be equaled or exceeded in any particular year. A 0.2-percent flood probability has a 1 in 500 chance of occurring during any year. The traditional concept of flood-recurrence interval is directly related to flood probability and is the reciprocal of the flood probability. For example, if a specific flood magnitude has a 1 in 100 chance of occurring in a given year (a 1-percent flood probability), then the average recurrence interval between floods of this magnitude is 100 years. This flood magnitude is referred to as the 100-year flood.

Flood probabilities allow city planners, highway engineers, and water managers to assess the likelihood of when another flood of similar magnitude might occur. Flood probabilities are estimated using a variety of techniques. All techniques ultimately are based on the history of actual annual peak discharges measured at one or more streamgages.

The method described in Bulletin 17B of the Interagency Advisory Committee on Water Data (1982) was used to estimate flood probabilities for streamgages in Iowa to indicate the relative magnitude of the May and June 2008 floods. Discharge estimates for selected flood-probability percentages $(20,10,4,2,1$, and 0.2$)$ were computed by fitting annual peak-discharge data for streamgages to a log-Pearson Type III distribution.

The accuracy and reliability of Bulletin 17B floodprobability estimation is dependent on several assumptions (Interagency Advisory Committee on Water Data, 1982) most notably that previous flood discharges are accurate and reliable indicators of future flood discharges. Bulletin 17B flood-probability estimation also assumes that the flood record is an accurate depiction of previous floods, and that the flood process can be represented mathematically as a sequence of independent annual maximum discharges that are randomly sampled from a population of all possible flood discharges. Bulletin 17B flood-probability estimates have substantial uncertainties (Subcommittee on Hydrology, 2008). Flood probabilities are reported as a range, except for those less than the 0.2 percent, to indicate the considerable amount of uncertainty in these estimates. If two independent estimates of flood probability are available, computing a weighted average of the two estimates will lower the uncertainty of either independent estimate (Interagency Advisory Committee on Water Data, 1982). Therefore, the method outlined in Bulletin 17B, appendix 8 was used where possible to achieve lower uncertainty in the estimation of flood probabilities. The weighted average was computed as the inverse of the respective variances of the two independent estimates.

For Iowa, the second independent estimate for each rural streamgage was obtained by use of regional-regression equations (Eash, 2001, 2003). At some locations, the regionalregression equations were not applied because the streamgages were in urban areas or were controlled by upstream reservoir releases. For streamgages without a second independent estimate for flood probabilities, Bulletin 17B estimates were used with no weighting method applied. For streamgages with less than 10 years of record, regional-regression equations were used.

The USGS uses U.S. Army Corps of Engineers (USACE) flood-probability estimates at sites where a river is controlled by upstream major impoundments. Interior stream segments in Iowa that are controlled by major impoundments are the Iowa River downstream from Coralville Reservoir, the Des Moines River downstream from Saylorville Reservoir, and the Chariton River downstream from Rathbun Reservoir. Floodprobability estimates for the affected streamgages on the Iowa and Des Moines Rivers are provided by USACE (2009) and the Hydrologic Engineering Center (2002). Flood-probability estimates for the affected streamgages on the Chariton River are provided by the St. Louis District USACE.

Theoretical flood-probability estimates computed for Iowa streamgages from two independent estimates, Bulletin 17B estimates or USACE estimates for controlled sites, can then be used to estimate the range of flood probabilities for 2008 floods by means of two approaches. The upper and lower bounds for the range of probability were determined by comparing a particular flood discharge directly to discharge estimates for selected flood probabilities. This method failed to consider the uncertainty of the discharge estimates for the selected probabilities. An alternative approach is to determine the 95-percent confidence intervals for discharges of the selected probabilities and to compare the particular flood discharge to these confidence intervals. Because of the uncertainty of estimating flood probabilities, the 95-percent confidence-interval range also was considered to be a likely estimate for the particular peak. In cases where the flood peak was within the confidence interval for multiple probabilities, the estimated flood probability was reported as a range. 


\section{Floods of May and June 2008}

Flooding occurred at various times and places throughout Iowa during 2008 in response to major rainfall events or a series of rainfall events. New flood-peak discharges were recorded at many streamgages. Peak-discharge and peak-stage data and estimated flood probabilities for the May and June 2008 floods at 62 selected USGS streamgages in Iowa are presented in table 2. Streamgages with new peak-discharge records established during May and June 2008 or where flood probability based on an estimate were 1 percent or smaller were selected for table 2 . The locations of the 62 streamgages listed in table 2 are shown on figure 1.

New record high discharges of the floods of May and June 2008 in Iowa began in late May at two streamgages (05451955, map no. 2 and 05464220 , map no. 4 ) south of Waterloo following more than 3 in. of rainfall in the area on May 26 (National Weather Service, 2009). Beginning on June 5, new record peak discharges were recorded for 11 of 12 consecutive days. Sixteen new record peak discharges were recorded on June 8, across a considerable area of the northern one-half of Iowa, mainly from central Iowa to near Dubuque. Flooding in the Mason City area was particularly noteworthy in early June after more than 4 in. of rain fell across northern Iowa (National Weather Service, 2009), with the Winnebago River at Mason City streamgage $(05459500,76$ years of record, map no. 18) exceeding its previous high discharge $[10,800$ cubic feet per second $\left.\left(\mathrm{ft}^{3} / \mathrm{s}\right)\right]$ by more than 21 percent $\left(13,100 \mathrm{ft}^{3} / \mathrm{s}\right)$ and the Shell Rock River at Shell Rock streamgage (05462000, 56 years of record, map no. 40) exceeding its previous high discharge $\left(45,000 \mathrm{ft}^{3} / \mathrm{s}\right)$ by more than 33 percent $\left(60,400 \mathrm{ft}^{3} / \mathrm{s}\right)$. The estimated flood probabiliy for these two streamgages was 0.2 to 1 (500 to 100 years) and less than 0.2 (more than 500 years), respectively. Water from the Winnebago and Shell Rock Rivers flows into the Cedar River upstream from Waterloo.

On June 9, 2008, seven new record high discharges were recorded mainly in the Decorah area in response to the June 8 rainfall. The Upper Iowa River at Decorah $(05387500,57$ years of record, map no. 27) exceeded its previously record high discharge $\left(20,500 \mathrm{ft}^{3} / \mathrm{s}\right)$ by about 66 percent $\left(34,100 \mathrm{ft}^{3} / \mathrm{s}\right)$. The estimated flood probability for this streamgage is 0.2 to 1 (500 to 100 years).
Beginning on June 10, new record peak discharges were recorded in the upstream reaches of the Cedar River. Streamflow from the Winnebago and Shell Rock Rivers described previously combined with streamflow from the upstream reaches of the Cedar River at Charles City (05457700, map no. 32) and the Little Cedar River near Ionia (05458000, map no. 33). This combined flow resulted in a new record peak discharge $\left(112,000 \mathrm{ft}^{3} / \mathrm{s}\right), 46$ percent larger (flood probability 0.2 to 1$)$ than the previous peak discharge at the Cedar River at Waterloo streamgage ( 05464000,72 years of record, map no. 42) on June 11. An additional 3 in. or more of rain fell in the Cedar Rapids area as the discharge in the river was peaking (National Weather Service, 2009). The new record peak discharge at Cedar Rapids $\left(05454500,140,000 \mathrm{ft}^{3} / \mathrm{s}\right.$, map no. 48) on June 13 was nearly 92 percent larger than the previous record. The estimated flood probability at Cedar Rapids is less than 0.2 (more than 500 years). The annual peak discharges for the period of record for the Cedar Rapids streamgage are shown on figure 4.

Record peak discharges were recorded on the middle reaches of the Des Moines (05481650, map no. 49), Iowa (05453100, map no. 43), and Wapsipinicon (05421740, map no. 46) Rivers on June 12 through 13. The downstream reaches of the Cedar, Iowa, and Wapsipinicon Rivers recorded new record high discharges from June 14 to 16 . A new record peak discharge $\left(41,100 \mathrm{ft}^{3} / \mathrm{s}\right)$ was measured at the Iowa River

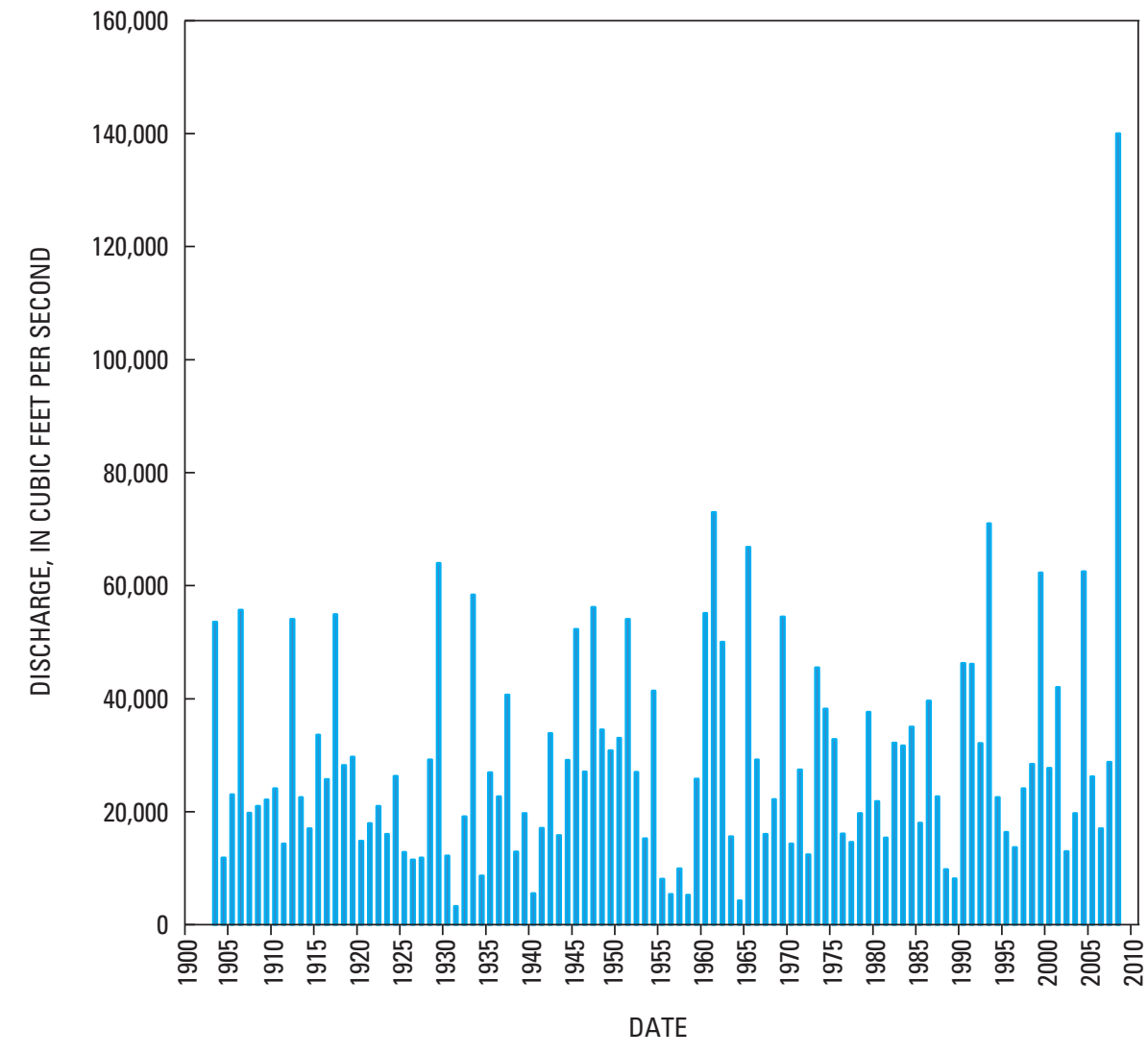

Figure 4. Historic annual peak discharges for the Cedar River at Cedar Rapids (05464500) streamgage, 1903 to 2008. 
Table 2. Flood-peak stage and discharge for selected lowa streamgages where a new peak-discharge record was recorded or where the flood-probability was estimated to be 1 percent or less during May and June 2008.

[Peak of record shown in bold. $\mathrm{mi}^{2}$, square miles; ft, feet; $\mathrm{ft}^{3} / \mathrm{s}$, cubic feet per second; ND, not determined; RRE, regional-regression equations from Eash $(2001)$; $<$, less than; WIE, flood probabilities calculated using weighting of independent estimates method (Interagency Advisory Committee on Water Data, 1982, appendix 8; C. Berenbrock and T. Cohn, U.S. Geological Survey, written commun., 2008); >, more than; B17B, Bulletin 17B method for calculating flood probabilities (Interagency Advisory Committee on Water Data, 1982); USACE, U.S. Army Corps of Engineers]

\begin{tabular}{|c|c|c|c|c|c|c|c|c|c|c|c|c|c|}
\hline \multirow[b]{3}{*}{$\begin{array}{c}\text { Map } \\
\text { number } \\
\text { (fig. 1) }\end{array}$} & \multirow[b]{3}{*}{$\begin{array}{c}\text { Streamgage } \\
\text { number }\end{array}$} & \multirow[b]{3}{*}{ Streamgage name and location } & \multirow[b]{3}{*}{$\begin{array}{c}\text { Drainage } \\
\text { area } \\
\left(\mathrm{mi}^{2}\right)\end{array}$} & \multirow[b]{3}{*}{$\begin{array}{c}\text { Period } \\
\text { of peak-flow } \\
\text { record } \\
\text { (water years) }\end{array}$} & \multirow{2}{*}{\multicolumn{3}{|c|}{ Maximum prior to 2008 flood }} & \multicolumn{6}{|c|}{ Maximum for 2008 flood } \\
\hline & & & & & & & & \multirow[b]{2}{*}{ Date } & \multirow[b]{2}{*}{$\begin{array}{l}\text { Peak } \\
\text { stage } \\
\text { (ft) }\end{array}$} & \multirow[b]{2}{*}{$\begin{array}{c}\text { Peak } \\
\text { discharge } \\
\left(\mathrm{ft}^{3} / \mathrm{s}\right)\end{array}$} & \multicolumn{3}{|c|}{ Estimated flood-probability range } \\
\hline & & & & & Date & $\begin{array}{c}\text { Peak } \\
\text { stage } \\
\text { (ft) }\end{array}$ & $\begin{array}{c}\text { Peak } \\
\text { discharge } \\
\left(\mathrm{ft}^{3} / \mathrm{s}\right)\end{array}$ & & & & $\begin{array}{l}\text { Based on } \\
\text { estimate }^{a} \\
\text { (percent) }\end{array}$ & $\begin{array}{c}\text { Based on } \\
\text { 95-percent } \\
\text { confidence } \\
\text { intervals } \\
\text { (percent) }\end{array}$ & $\begin{array}{c}\text { Probability } \\
\text { calculation } \\
\text { method }\end{array}$ \\
\hline 1 & 05416900 & Maquoketa River at Manchester & 275 & $2001-08$ & $5 / 23 / 2004$ & 21.66 & 26,000 & $5 / 26 / 2008$ & 20.80 & 22,100 & $0.2-1$ & ND & RRE \\
\hline 2 & 05451955 & Stein Creek near Clutier & 23.4 & $1972-2008$ & $6 / 15 / 1982$ & 77.92 & 11,400 & $5 / 30 / 2008$ & 78.02 & 12,200 & $<.2$ & $<.2-1$ & WIE \\
\hline 3 & 05452000 & Salt Creek near Elberon & 201 & $1944,1946-2008$ & 7/9/1993 & 20.85 & 36,600 & $5 / 30 / 2008$ & 19.75 & 22,400 & $.2-1$ & $<.2-4$ & WIE \\
\hline 4 & 05464220 & Wolf Creek near Dysart & 299 & $1996-98,2002-08$ & $5 / 23 / 2004$ & 17.39 & 14,500 & $5 / 30 / 2008$ & 18.25 & 15,700 & $2-4$ & $.2-10$ & WIE \\
\hline 5 & 05470500 & Squaw Creek at Ames & 204 & $\begin{array}{l}1918,1920-27 \\
1965-2008\end{array}$ & 7/9/1993 & 18.54 & 24,300 & $5 / 30 / 2008$ & 15.85 & 12,600 & $1-2$ & $.2-4$ & WIE \\
\hline 6 & 05471000 & $\begin{array}{l}\text { South Skunk River below Squaw } \\
\text { Creek near Ames }\end{array}$ & 556 & $\begin{array}{l}1944,1953-79 \\
1990-2008\end{array}$ & $7 / 9 / 1993$ & $\mathrm{c} 25.57$ & 26,500 & $5 / 30 / 2008$ & 24.70 & 19,800 & $.2-1$ & $<.2-4$ & WIE \\
\hline 7 & 06817000 & Nodaway River at Clarinda & 762 & $\begin{array}{c}1918-25 \\
1936-2008\end{array}$ & $6 / 13 / 1947^{\mathrm{d}}$ & 25.30 & 31,100 & $6 / 5 / 2008$ & 26.61 & 47,900 & $<.2$ & $<.2-1$ & WIE \\
\hline 8 & 05459490 & Spring Creek near Mason City & 29.3 & $1966-2008$ & $5 / 22 / 2004$ & 91.15 & 5,340 & $6 / 6 / 2008$ & 92.91 & 4,680 & $1-2$ & $<.2-10$ & WIE \\
\hline 9 & 05485640 & Fourmile Creek at Des Moines & 92.7 & $1972-2008$ & $6 / 18 / 1998$ & 15.00 & 5,600 & $6 / 6 / 2008$ & ${ }^{\mathrm{c}} 15.14$ & 6,810 & $2-4$ & $.2-10$ & WIE \\
\hline 10 & 05387490 & Dry Run Creek near Decorah & 21 & $\begin{array}{l}1978,1980,1984- \\
85,1987-2008\end{array}$ & $8 / 16 / 1993$ & 20.80 & 4,620 & $6 / 8 / 2008$ & 21.53 & 5,820 & $1-2$ & $1-2$ & WIE \\
\hline 11 & 05414350 & Little Maquoketa River near Graf & 39.6 & 1951-2008 & $6 / 4 / 2002$ & 15.93 & 7,700 & $6 / 8 / 2008$ & 16.47 & 8,370 & $2-4$ & $.2-10$ & WIE \\
\hline 12 & 05414450 & $\begin{array}{l}\text { North Fork Little Maquoketa River } \\
\text { near Rickardsville }\end{array}$ & 21.6 & $1951-2008$ & 8/2/1972 & 14.02 & 7,180 & $6 / 8 / 2008$ & 12.58 & 8,040 & $.2-1$ & $<.2-4$ & WIE \\
\hline 13 & 05414605 & Bloody Run Tributary near Sherrill & .59 & $1991-2008$ & $6 / 15 / 1991$ & 19.27 & ${ }^{\mathrm{e}} 692$ & $6 / 8 / 2008$ & 22.71 & 1,110 & $2-4$ & $1->10$ & B17B \\
\hline 14 & 05451080 & $\begin{array}{l}\text { South Fork Iowa River near } \\
\text { Blairsburg }\end{array}$ & 12 & $2006-08$ & $3 / 12 / 2007$ & 11.79 & 227 & $6 / 8 / 2008$ & 12.50 & 762 & $.2-1$ & $\mathrm{ND}$ & RRE \\
\hline 15 & 05451210 & $\begin{array}{l}\text { South Fork Iowa River northeast of } \\
\text { New Providence }\end{array}$ & 224 & $1996-2008$ & $6 / 23 / 2007$ & ${ }^{\mathrm{c}} 11.59$ & 3,910 & $6 / 8 / 2008$ & 13.84 & 7,390 & $2-4$ & $1-10$ & WIE \\
\hline 16 & 0545129280 & $\begin{array}{l}\text { Honey Creek Tributary near } \\
\text { Radcliffe }\end{array}$ & 3.29 & $\begin{array}{l}\text { 1991-93, } \\
1995-2008\end{array}$ & $5 / 10 / 1995$ & 100.14 & e 510 & $6 / 8 / 2008$ & 100.23 & '511 & $>10$ & $4->10$ & WIE \\
\hline 17 & 05457440 & Deer Creek near Carpenter & 91.6 & $1973-2008$ & $7 / 6 / 2004$ & 85.75 & 4,150 & $6 / 8 / 2008$ & 87.86 & 11,800 & $<.2$ & $<.2-1$ & WIE \\
\hline 18 & 05459500 & Winnebago River at Mason City & 526 & $1933-2008$ & $3 / 30 / 1933$ & 15.70 & 10,800 & $6 / 8 / 2008$ & 18.74 & 13,100 & $.2-1$ & $<.2-4$ & WIE \\
\hline 19 & 05460100 & Willow Creek near Mason City & 78.6 & $\begin{array}{l}1966-89 \\
1991-2008\end{array}$ & $5 / 22 / 2004$ & 92.21 & 1,270 & $6 / 8 / 2008$ & 93.28 & 2,380 & $.2-1$ & $<.2-2$ & WIE \\
\hline 20 & 05463000 & Beaver Creek at New Hartford & 347 & $1946-2008$ & 6/13/1947 & 13.50 & 18,000 & $6 / 8 / 2008$ & 15.71 & 25,900 & $.2-1$ & $<.2-2$ & WIE \\
\hline
\end{tabular}


Table 2. Flood-peak stage and discharge for selected lowa streamgages where a new peak-discharge record was recorded or where the flood-probability was estimated to be 1 percent or less during May and June 2008.-Continued

[Peak of record shown in bold. $\mathrm{mi}^{2}$, square miles; ft, feet; $\mathrm{ft}^{3} / \mathrm{s}$, cubic feet per second; ND, not determined; RRE, regional-regression equations from Eash (2001); <, less than; WIE, flood probabilities calculated using weighting of independent estimates method (Interagency Advisory Committee on Water Data, 1982, appendix 8; C. Berenbrock and T. Cohn, U.S. Geological Survey, written commun., 2008); >, more than; B17B, Bulletin 17B method for calculating flood probabilities (Interagency Advisory Committee on Water Data, 1982); USACE, U.S. Army Corps of Engineers]

\begin{tabular}{|c|c|c|c|c|c|c|c|c|c|c|c|c|c|}
\hline \multirow[b]{3}{*}{$\begin{array}{l}\text { Map } \\
\text { number } \\
\text { (fig. 1) }\end{array}$} & \multirow[b]{3}{*}{$\begin{array}{c}\text { Streamgage } \\
\text { number }\end{array}$} & \multirow[b]{3}{*}{ Streamgage name and location } & \multirow[b]{3}{*}{$\begin{array}{l}\text { Drainage } \\
\text { area } \\
\left(\mathrm{mi}^{2}\right)\end{array}$} & \multirow[b]{3}{*}{$\begin{array}{c}\text { Period } \\
\text { of peak-flow } \\
\text { record } \\
\text { (water years) }\end{array}$} & \multirow{2}{*}{\multicolumn{3}{|c|}{ Maximum prior to 2008 flood }} & \multicolumn{6}{|c|}{ Maximum for 2008 flood } \\
\hline & & & & & & & & \multirow[b]{2}{*}{ Date } & \multirow[b]{2}{*}{$\begin{array}{l}\text { Peak } \\
\text { stage } \\
\text { (ft) }\end{array}$} & \multirow[b]{2}{*}{$\begin{array}{c}\text { Peak } \\
\text { discharge } \\
\left(\mathrm{ft}^{3} / \mathrm{s}\right)\end{array}$} & \multicolumn{3}{|c|}{ Estimated flood-probability range } \\
\hline & & & & & Date & $\begin{array}{c}\text { Peak } \\
\text { stage } \\
\text { (ft) }\end{array}$ & $\begin{array}{c}\text { Peak } \\
\text { discharge } \\
\left(\mathrm{ft}^{3} / \mathrm{s}\right)\end{array}$ & & & & $\begin{array}{l}\text { Based on } \\
\text { estimate }^{a} \\
\text { (percent) }\end{array}$ & $\begin{array}{l}\text { Based on } \\
\text { 95-percent } \\
\text { confidence } \\
\text { intervals } \\
\text { (percent) }\end{array}$ & $\begin{array}{l}\text { Probability } \\
\text { calculation } \\
\text { method }\end{array}$ \\
\hline 21 & 05469860 & $\begin{array}{l}\text { Mud Lake Drainage Ditch } 71 \text { at } \\
\text { Jewell }\end{array}$ & 65.4 & $1966-2008$ & 7/9/1993 & 91.32 & 3,700 & $6 / 8 / 2008$ & 91.87 & 3,120 & $1-2$ & $<0.2-4$ & WIE \\
\hline 22 & 05480930 & White Fox Creek at Clarion & 13.3 & 1966-2008 & 7/9/1993 & c93.77 & 1,400 & $6 / 8 / 2008$ & 93.85 & 1,480 & $1-2$ & $<.2-10$ & WIE \\
\hline 23 & 05482900 & Hardin Creek near Farlin & 101 & $\begin{array}{l}\text { 1951-93, } \\
1995-2008\end{array}$ & 7/9/1993 & 13.97 & 3,010 & $6 / 8 / 2008$ & 13.40 & 3,030 & $1-2$ & $.2-10$ & WIE \\
\hline 24 & 0660683710 & Halfway Creek at Schaller & 1.74 & 1990-2008 & $5 / 6 / 2007$ & 94.64 & 486 & $6 / 8 / 2008$ & 97.31 & 1,010 & $4-10$ & $2->10$ & WIE \\
\hline 25 & 06609500 & Boyer River at Logan & 871 & $\begin{array}{l}1881,1918-25 \\
1938-2008\end{array}$ & $6 / 17 / 1990$ & ${ }^{c} 25.22$ & 30,800 & $6 / 8 / 2008$ & 24.75 & 33,600 & $1-2$ & $<.2-4$ & WIE \\
\hline 26 & 05387440 & Upper Iowa River at Bluffton & 367 & 2003-08 & $8 / 22 / 2007$ & 12.66 & 8,440 & 6/9/2008 & 15.49 & 16,600 & $2-4$ & ND & RRE \\
\hline 27 & 05387500 & Upper Iowa River at Decorah & 511 & $1952-2008$ & 8/17/1993 & ${ }^{\mathrm{e}} 14.35$ & e20,500 & $6 / 9 / 2008$ & 17.90 & 34,100 & ${ }^{\mathrm{f}} .2-1$ & $\mathrm{f}<.2-1$ & WIE \\
\hline 28 & 05388250 & Upper Iowa River, at Dorchester & 770 & $\begin{array}{l}\text { 1941, 1976-95, } \\
1997-2008\end{array}$ & $5 / 31 / 1941$ & 21.80 & 30,400 & $6 / 9 / 2008$ & 22.46 & 31,200 & $.2-1$ & $.2-4$ & WIE \\
\hline 29 & 05411850 & Turkey River near Eldorado & 641 & 1991, 2001-08 & $5 / 23 / 2004$ & 19.61 & 19,700 & 6/9/2008 & 21.46 & 50,100 & $<.2$ & ND & RRE \\
\hline 30 & 05420680 & Wapsipinicon River near Tripoli & 346 & 1997-2008 & $7 / 21 / 1999$ & 18.50 & 19,400 & 6/9/2008 & 18.24 & 18,300 & $1-2$ & $.2-10$ & WIE \\
\hline 31 & 05449500 & Iowa River near Rowan & 429 & $\begin{array}{l}\text { 1941-76, } \\
1978-2008\end{array}$ & $6 / 21 / 1954$ & 14.88 & 8,460 & $6 / 9 / 2008$ & 15.89 & 7,890 & $1-2$ & $.2-10$ & WIE \\
\hline 32 & 05457700 & Cedar River at Charles City & 1,054 & $\begin{array}{c}1946-53,1961-62 \\
1965-2008\end{array}$ & $7 / 21 / 1999$ & 22.81 & 31,200 & $6 / 9 / 2008$ & 25.33 & 34,600 & $.2-1$ & $<.2-4$ & WIE \\
\hline 33 & 05458000 & Little Cedar River near Ionia & 306 & 1954-2008 & $8 / 16 / 1993$ & 18.99 & 14,000 & 6/9/2008 & 21.32 & 24,700 & $.2-1$ & $<.2-2$ & WIE \\
\hline 34 & 05470000 & South Skunk River near Ames & 315 & $\begin{array}{l}1921-27,1930 \\
1933-2008\end{array}$ & $7 / 17 / 1996^{\mathrm{g}}$ & 15.89 & ${ }^{\mathrm{e}} 14,000$ & 6/9/2008 & 16.93 & 11,000 & $1-2$ & $.2-4$ & WIE \\
\hline 35 & 05481300 & Des Moines River near Stratford & 5,452 & 1968-2008 & $4 / 2 / 1993$ & 25.68 & 42,300 & $6 / 9 / 2008$ & 27.32 & 50,300 & ${ }^{\mathrm{h}} 1-2$ & ${ }^{\mathrm{h}} \cdot 2-4$ & WIE \\
\hline 36 & 05412020 & $\begin{array}{l}\text { Turkey River above French Hollow } \\
\text { Creek at Elkader }\end{array}$ & 903 & $1991,2002-08$ & $6 / 15 / 1991$ & 27.32 & 38,300 & $6 / 10 / 2008$ & 27.77 & 40,500 & $.2-1$ & $\mathrm{ND}$ & RRE \\
\hline 37 & 05412500 & Turkey River at Garber & 1,545 & $\begin{array}{c}1902,1914-16 \\
1919-27,1930 \\
1933-2008\end{array}$ & $5 / 23 / 2004$ & 32.80 & 66,700 & $6 / 10 / 2008$ & 29.13 & 45,500 & $1-2$ & $.2-4$ & WIE \\
\hline 38 & 05458300 & Cedar River at Waverly & 1,547 & $2001-08$ & $4 / 14 / 2001$ & ' 13.16 & 25,600 & $6 / 10 / 2008$ & 19.33 & 52,600 & ${ }^{i}<.2$ & ${ }^{\mathrm{i}} \mathrm{ND}$ & RRE \\
\hline 39 & 05458500 & Cedar River at Janesville & 1,661 & $\begin{array}{c}1905-06,1915-21 \\
1923-27,1933-42, \\
1945-2008\end{array}$ & $7 / 22 / 1999$ & 17.15 & 42,200 & $6 / 10 / 2008$ & 19.45 & 53,400 & $.2-1$ & $<.2-1$ & WIE \\
\hline
\end{tabular}


Table 2. Flood-peak stage and discharge for selected lowa streamgages where a new peak-discharge record was recorded or where the flood-probability was estimated to be 1 percent or less during May and June 2008.-Continued

[Peak of record shown in bold. $\mathrm{mi}^{2}$, square miles; ft, feet; $\mathrm{ft}^{3} / \mathrm{s}$, cubic feet per second; ND, not determined; RRE, regional-regression equations from Eash (2001); <, less than; WIE, flood probabilities calculated using weighting of independent estimates method (Interagency Advisory Committee on Water Data, 1982, appendix 8; C. Berenbrock and T. Cohn, U.S. Geological Survey, written commun., 2008); >, more than; B17B, Bulletin 17B method for calculating flood probabilities (Interagency Advisory Committee on Water Data, 1982); USACE, U.S. Army Corps of Engineers]

\begin{tabular}{|c|c|c|c|c|c|c|c|c|c|c|c|c|c|}
\hline \multirow[b]{3}{*}{$\begin{array}{l}\text { Map } \\
\text { number } \\
\text { (fig. 1) }\end{array}$} & \multirow[b]{3}{*}{$\begin{array}{c}\text { Streamgage } \\
\text { number }\end{array}$} & \multirow[b]{3}{*}{ Streamgage name and location } & \multirow[b]{3}{*}{$\begin{array}{c}\text { Drainage } \\
\text { area } \\
\left(\mathrm{mi}^{2}\right)\end{array}$} & \multirow[b]{3}{*}{$\begin{array}{c}\text { Period } \\
\text { of peak-flow } \\
\text { record } \\
\text { (water years) }\end{array}$} & \multirow{2}{*}{\multicolumn{3}{|c|}{ Maximum prior to 2008 flood }} & \multicolumn{6}{|c|}{ Maximum for 2008 flood } \\
\hline & & & & & & & & \multirow[b]{2}{*}{ Date } & \multirow[b]{2}{*}{$\begin{array}{c}\text { Peak } \\
\text { stage } \\
(\mathrm{ft})\end{array}$} & \multirow[b]{2}{*}{$\begin{array}{c}\text { Peak } \\
\text { discharge } \\
\left(\mathrm{ft}^{3} / \mathrm{s}\right)\end{array}$} & \multicolumn{3}{|c|}{ Estimated flood-probability range } \\
\hline & & & & & Date & $\begin{array}{c}\text { Peak } \\
\text { stage } \\
\text { (ft) }\end{array}$ & $\begin{array}{c}\text { Peak } \\
\text { discharge } \\
\left(\mathrm{ft}^{3} / \mathrm{s}\right)\end{array}$ & & & & $\begin{array}{l}\text { Based on } \\
\text { estimate }^{a} \\
\text { (percent) }\end{array}$ & $\begin{array}{c}\text { Based on } \\
\text { 95-percent } \\
\text { confidence } \\
\text { intervals }^{\mathrm{b}} \\
\text { (percent) }\end{array}$ & $\begin{array}{c}\text { Probability } \\
\text { calculation } \\
\text { method }\end{array}$ \\
\hline 40 & 05462000 & Shell Rock River at Shell Rock & 1,746 & $1856,1954-2008$ & $1 / 29 / 1905$ & ${ }^{\mathrm{j}} 17.70$ & ${ }^{\mathrm{e}} 45,000$ & $6 / 10 / 2008$ & 20.36 & 60,400 & $<0.2$ & $<0.2-1$ & WIE \\
\hline 41 & 05481000 & Boone River near Webster City & 844 & $\begin{array}{l}1918,1932 \\
1941-2008\end{array}$ & $6 / 10 / 1918$ & 19.10 & 21,500 & $6 / 10 / 2008$ & 17.74 & k20,500 & $.2-1$ & $<.2-4$ & WIE \\
\hline 42 & 05464000 & Cedar River at Waterloo & 5,146 & $\begin{array}{l}1929,1933 \\
1941-2008\end{array}$ & $3 / 29 / 1961$ & 21.86 & 76,700 & $6 / 11 / 2008$ & 27.01 & 112,000 & $.2-1$ & $<.2-4$ & B17B \\
\hline 43 & 05453100 & Iowa River at Marengo & 2,794 & $1957-2008$ & $7 / 19 / 1993$ & 20.31 & 38,000 & $6 / 12 / 2008$ & 21.38 & 51,000 & $.2-1$ & $<.2-2$ & WIE \\
\hline 44 & 05454180 & $\begin{array}{l}\text { Clear Creek tributary near Wil- } \\
\text { liamsburg }\end{array}$ & .37 & 1990-2008 & $6 / 22 / 2007$ & 49.18 & 328 & $6 / 12 / 2008$ & 49.37 & 346 & $4-10$ & $2->10$ & B17B \\
\hline 45 & 06816290 & West Nodaway River at Massena & 23.4 & $1966-2008$ & $2 / 1 / 1973$ & 82.39 & ${ }^{\bullet} 4,700$ & $6 / 12 / 2008$ & 80.54 & 4,850 & $2-4$ & $.2-10$ & WIE \\
\hline 46 & 05421740 & Wapsipinicon River near Anamosa & 1,575 & 2003-08 & $5 / 26 / 2004$ & 22.73 & 22,000 & $6 / 13 / 2008$ & 26.18 & 31,800 & $2-4$ & $\mathrm{ND}$ & B17B \\
\hline 47 & 05422600 & $\begin{array}{l}\text { Duck Creek at Duck Creek Golf } \\
\text { Course at Davenport }\end{array}$ & 57.3 & 1994-2008 & $6 / 4 / 2002$ & 16.34 & 7,310 & $6 / 13 / 2008$ & 16.60 & $\mathbf{7 , 5 7 0}$ & $4-10$ & $1->10$ & B17B \\
\hline 48 & 05464500 & Cedar River at Cedar Rapids & 6,510 & $1851,1903-2008$ & $3 / 31 / 1961$ & ${ }^{\prime} 20.00$ & 73,000 & $6 / 13 / 2008$ & 31.12 & 140,000 & $<.2$ & $<.2-1$ & B17B \\
\hline 49 & 05481650 & Des Moines River near Saylorville & 5,841 & $1954,1962-2008$ & $7 / 21 / 1993^{\mathrm{m}}$ & $c 24.22$ & ${ }^{\mathrm{n}} 45,700$ & $6 / 13 / 2008$ & 24.03 & ${ }^{\mathrm{n}} \mathbf{5 0 , 5 0 0}$ & ${ }^{0}<.2$ & $\mathrm{ND}^{\circ}$ & USACE \\
\hline 50 & 05482000 & $\begin{array}{l}\text { Des Moines River at 2nd Avenue } \\
\text { at Des Moines }\end{array}$ & 6,245 & $\begin{array}{c}1902-03,1906 \\
1915-61 \\
1997-2008\end{array}$ & $4 / 17 / 2001^{\mathrm{m}}$ & $c 20.72$ & $\mathrm{p} 18,500$ & $6 / 13 / 2008$ & 31.57 & $\mathrm{p} 47,300$ & ${ }^{\circ} .2-1$ & $\mathrm{ND}^{\circ}$ & USACE \\
\hline 51 & 05484650 & $\begin{array}{l}\text { Raccoon River at 63rd Street at } \\
\text { Des Moines }\end{array}$ & 3,529 & 1992-2008 & $7 / 11 / 1993$ & 40.77 & 66,000 & $6 / 13 / 2008$ & 41.31 & 52,000 & $1-2$ & $.2-4$ & WIE \\
\hline 52 & 05484900 & $\begin{array}{l}\text { Raccoon River at Fleur Drive at } \\
\text { Des Moines }\end{array}$ & 3,625 & $\begin{array}{l}1984-87 \\
1989-2008\end{array}$ & $7 / 11 / 1993$ & 26.80 & 67,900 & $6 / 13 / 2008$ & 24.66 & 56,300 & $1-2$ & $<.2-4$ & WIE \\
\hline 53 & 05485500 & $\begin{array}{l}\text { Des Moines River below Raccoon } \\
\text { River at Des Moines }\end{array}$ & 9,879 & $1903,1940-2008$ & $7 / 11 / 1993^{\mathrm{m}}$ & 34.29 & 116,000 & $6 / 13 / 2008$ & 35.55 & 104,000 & ${ }^{\circ} .2-1$ & $\mathrm{ND}^{\circ}$ & USACE \\
\hline 54 & 05465000 & Cedar River near Conesville & 7,787 & 1929, 1940-2008 & $4 / 6 / 1993$ & 17.11 & 74,000 & $6 / 14 / 2008$ & 23.40 & 127,000 & $.2-1$ & $<.2-2$ & B17B \\
\hline 55 & 05465500 & Iowa River at Wapello & 12,500 & 1903-2008 & $7 / 8 / 1993^{\mathrm{m}}$ & $c 29.53$ & 111,000 & $6 / 14 / 2008$ & 32.15 & 188,000 & $\mathrm{q}<.2$ & $\mathrm{ND}^{q}$ & USACE \\
\hline 56 & 05488500 & Des Moines River near Tracy & 12,479 & $1903,1920-2008$ & $7 / 12 / 1993^{\mathrm{m}}$ & 24.16 & ${ }^{\mathrm{r}} 109,000$ & $6 / 14 / 2008$ & 23.70 & 104,000 & ${ }^{\circ} .2-1$ & $\mathrm{ND}^{\circ}$ & USACE \\
\hline 57 & 05453520 & $\begin{array}{l}\text { Iowa River below Coralville Dam, } \\
\text { Coralville }\end{array}$ & 3,115 & 1993-2008 & $7 / 19 / 1993$ & 63.95 & 25,800 & $6 / 15 / 2008$ & 68.09 & 39,900 & ${ }^{9} .2-1$ & $\mathrm{ND}^{\mathrm{q}}$ & USACE \\
\hline 58 & 05454500 & Iowa River at Iowa City & 3,271 & $\begin{array}{l}1851,1881 \\
1903-2008\end{array}$ & $8 / 10 / 1993^{\mathrm{m}}$ & 28.52 & $s 28,200$ & $6 / 15 / 2008$ & 31.53 & $\mathrm{~s}^{\mathrm{4}} \mathbf{4 1 , 1 0 0}$ & ${ }^{\natural} .2-1$ & $\mathrm{ND}^{\mathrm{q}}$ & USACE \\
\hline 59 & 05455700 & Iowa River at Lone Tree & 4,293 & $1944,1957-2008$ & $7 / 7 / 1993^{\mathrm{m}}$ & 22.94 & 57,100 & $6 / 15 / 2008$ & 23.10 & 53,700 & ${ }^{\mathrm{q}} \cdot 2-1$ & $\mathrm{ND}^{\mathrm{q}}$ & USACE \\
\hline
\end{tabular}


Table 2. Flood-peak stage and discharge for selected lowa streamgages where a new peak-discharge record was recorded or where the flood-probability was estimated to be 1 percent or less during May and June 2008.-Continued

[Peak of record shown in bold. $\mathrm{mi}^{2}$, square miles; $\mathrm{ft}$, feet; $\mathrm{ft}^{3} / \mathrm{s}$, cubic feet per second; ND, not determined; RRE, regional-regression equations from Eash (2001); <, less than; WIE, flood probabilities calculated using weighting of independent estimates method (Interagency Advisory Committee on Water Data, 1982, appendix 8; C. Berenbrock and T. Cohn, U.S. Geological Survey, written commun., 2008); >, more than; B17B, Bulletin 17B method for calculating flood probabilities (Interagency Advisory Committee on Water Data, 1982); USACE, U.S. Army Corps of Engineers]

\begin{tabular}{|c|c|c|c|c|c|c|c|c|c|c|c|c|c|}
\hline \multirow[b]{3}{*}{$\begin{array}{l}\text { Map } \\
\text { number } \\
\text { (fig. 1) }\end{array}$} & \multirow[b]{3}{*}{$\begin{array}{c}\text { Streamgage } \\
\text { number }\end{array}$} & \multirow[b]{3}{*}{ Streamgage name and location } & \multirow[b]{3}{*}{$\begin{array}{l}\text { Drainage } \\
\text { area } \\
\left(\mathrm{mi}^{2}\right)\end{array}$} & \multirow[b]{3}{*}{$\begin{array}{c}\text { Period } \\
\text { of peak-flow } \\
\text { record } \\
\text { (water years) }\end{array}$} & \multirow{2}{*}{\multicolumn{3}{|c|}{ Maximum prior to 2008 flood }} & \multicolumn{6}{|c|}{ Maximum for 2008 flood } \\
\hline & & & & & & & & \multirow[b]{2}{*}{ Date } & \multirow[b]{2}{*}{$\begin{array}{l}\text { Peak } \\
\text { stage } \\
\text { (ft) }\end{array}$} & \multirow[b]{2}{*}{$\begin{array}{c}\text { Peak } \\
\text { discharge } \\
\left(\mathrm{ft}^{3} / \mathrm{s}\right)\end{array}$} & \multicolumn{3}{|c|}{ Estimated flood-probability range } \\
\hline & & & & & Date & $\begin{array}{c}\text { Peak } \\
\text { stage } \\
\text { (ft) }\end{array}$ & $\begin{array}{c}\text { Peak } \\
\text { discharge } \\
\left(f^{3} / s\right)\end{array}$ & & & & $\begin{array}{l}\text { Based on } \\
\text { estimate }^{a} \\
\text { (percent) }\end{array}$ & $\begin{array}{l}\text { Based on } \\
\text { 95-percent } \\
\text { confidence } \\
\text { intervals }^{b} \\
\text { (percent) }\end{array}$ & $\begin{array}{c}\text { Probability } \\
\text { calculation } \\
\text { method }\end{array}$ \\
\hline 60 & 05422000 & Wapsipinicon River at DeWitt & 2,336 & $1935-2008$ & $5 / 30 / 2004$ & ${ }^{\mathrm{c}} 14.19$ & 31,500 & $6 / 16 / 2008$ & 14.13 & 36,400 & $2-4$ & $0.2-10$ & WIE \\
\hline 61 & 05490500 & Des Moines River at Keosauqua & 14,038 & $\begin{array}{c}1851,1903-06 \\
1912-2008\end{array}$ & $7 / 12 / 1993^{\mathrm{m}}$ & 32.66 & t111,000 & $6 / 16 / 2008$ & 30.49 & 106,000 & ${ }^{\circ} .2-1$ & $\mathrm{ND}^{\circ}$ & USACE \\
\hline 62 & 05489500 & Des Moines River at Ottumwa & 13,374 & $1903,1917-2008$ & $7 / 12 / 1993^{\mathrm{m}}$ & 22.15 & u 112,000 & $6 / 17 / 2008$ & 20.60 & 102,000 & ${ }^{\circ} .2-1$ & $\mathrm{ND}^{\circ}$ & USACE \\
\hline
\end{tabular}

${ }^{a}$ Estimated flood-probability range based on estimate: The flood probability for a specific streamflow magnitude is the probability or chance of that streamflow being equaled or exceeded in any particular year. For example, a 1-percent-chance flood has a 1 in 100 chance of occurring in any particular year. Flood-recurrence interval, which is the reciprocal of the flood probability, is the statistical average number of years between exceedances of a specific streamflow magnitude. If a specific flood magnitude has a 1 in 100 chance of occurring in a particular year (a 1-percent chance flood), then the average recurrence interval between floods of this magnitude is 100 years. This flood magnitude is referred to as the 100 -year flood. Based on direct comparison of flood-peak discharge to the discharge estimates for various flood probabilities (traditional approach). Flood probabilities are reported as a range because of uncertainty in estimating flood-discharge probabilities. The reporting ranges are (ordered by decreasing probability): more than $10,4-10,2-4,1-2,0.2-1$, and less than 0.2 percent.

${ }^{\mathrm{b}}$ Estimated flood-probability range based on 95-percent confidence intervals: Based on comparison of flood-peak discharge to the lower and upper bounds of the 95-percent confidence limits for discharge estimates for multiple probabilities (alternative approach). Flood probabilities from 95-percent confidence intervals also are reported as a range because of uncertainty in estimating flood-discharge probabilities.

${ }^{\mathrm{c}}$ Maximum peak stage occurred on a different date than the maximum peak discharge.

${ }^{\mathrm{d}}$ Peak discharge of $31,100 \mathrm{ft}^{3} / \mathrm{s}$ also occurred during 2007 at a stage of $23.82 \mathrm{ft}$.

${ }^{e}$ Estimated.

${ }^{\mathrm{f}}$ Flood-probability estimates are based on inclusion of additional area-weighted annual-peak discharges from discontinued downstream gage (05388000).

${ }^{\mathrm{g}}$ Maximum occurred at a different site and datum of streamgage.

${ }^{\text {h }}$ Flood-probability estimates are based on inclusion of additional annual-peak discharges from discontinued downstream gage (05481500).

${ }^{1}$ Flood-probability estimates are based on logarithmic interpolation of weighted flood-probabillty discharge estimates between upstream gage (05421000) and downstream gage (05422000).

${ }^{j}$ Stage measured at bridge $400 \mathrm{ft}$ downstream, from information provided by U.S. Army Corps of Engineers

${ }^{\mathrm{k}}$ Record peak of systematic record: discharge of historic 1918 peak was $21,500 \mathrm{ft}^{3} / \mathrm{s}$.

${ }^{\mathrm{I}}$ Flood-probability estimates are based on weighted estimates from nearby downstream gage (05458500) and regional-regression estimates for this gage (05458300) (Eash, 2001, equation 4).

${ }^{\mathrm{m}}$ Maximum during post-regulation period of record. Post regulation on the Iowa River downstream from the Coralville Lake since September 17, 1958; on the Des Moines River downstream from Lake

Red Rock since March 12, 1969; and on the Des Moines River downstream from Saylorville Lake since April 12, 1977.

${ }^{\mathrm{n}}$ Record peak during regulated period of record (1977-2008): discharge of historic 1954 peak was 60,000 ft $/ \mathrm{s}$.

${ }^{\circ}$ Hydrologic Engineering Center (2002).

${ }^{\mathrm{p}}$ Record peak during regulated period of record (1997-2008): discharge of 1954 peak was $60,200 \mathrm{ft}^{3} / \mathrm{s}$.

${ }^{q}$ U.S. Army Corps of Engineers (2009).

${ }^{\mathrm{r}}$ Record peak during regulated period of record (1969-2008): discharge of 1947 peak was $155,000 \mathrm{ft}^{3} / \mathrm{s}$.

${ }^{s}$ Record peak during regulated period of record (1959-2008): discharge estimate of historic 1851 peak was 70,000 fts.s.

${ }^{t}$ Record peak during regulated period of record (1969-2008): discharge of 1903 peak was 146,000 ft³ $/ \mathrm{s}$.

${ }^{u}$ Record peak during regulated period of record (1969-2008): discharge estimate of historic 1903 peak was 140,000 fts. 
at Iowa City streamgage (05454500, 108 years of record, map no. 58) on June 15 that was 46 percent larger than the previous record set in 1993. The flood-probability estimate at Iowa City was 0.2 to 1 (500 to 100 years). The combined flow of the Cedar and Iowa Rivers was measured at the Iowa River at Wapello streamgage $(05465500,106$ years of record, map no. 55). The peak discharge at this streamgage in June 2008 was $188,000 \mathrm{ft}^{3} / \mathrm{s}$ (69 percent larger than the previous peak) with a flood-probability estimate of less than 0.2 (more than 500 years). Although no new historic peak discharges were established on the Des Moines River downstream from Des Moines, flood probabilities of 0.2 to 1 (500 to 100 years) were common.

\section{Summary}

An unusually wet winter and spring of 2007 to 2008 resulted in extremely wet antecedent conditions throughout most of Iowa. Rainfall of 5 to 15 inches was observed in eastern Iowa during May 2008 and an additional 5 to 15 inches of rain was observed throughout most of Iowa in June. Because of the severity of the May and June 2008 flooding, the U.S. Geological Survey, in cooperation with other Federal, State, and local agencies, has summarized the meteorological and hydrological conditions leading to the flooding, compiled flood-peak stages and discharges, and estimated revised flood probabilities for 62 selected streamgages.

Record peak discharges or flood probabilities of 1 percent or smaller (100-year flooding or greater) occurred at more than 60 streamgage locations, particularly in eastern Iowa. Cedar Rapids, Decorah, Des Moines, Iowa City, Mason City, and Waterloo were among the larger urban areas affected by this flooding. High water and flooding in small, headwater streams in north-central and eastern Iowa, particularly in June, combined and accumulated in large, mainstem rivers and resulted in flooding of historic proportions in the Cedar and Iowa Rivers. Previous flood peaks at many locations were exceeded by substantial amounts, in some cases nearly doubling the previous record peak at locations where more than 100 years of streamflow record are available.

\section{References Cited}

Eash, D.A., 2001, Techniques for estimating flood-frequency discharges for streams in Iowa: U.S. Geological Survey Water-Resources Investigations Report 00-4233, 88 p., accessed July 23, 2008, at http://pubs.er.usgs.gov/usgspubs/ wri/wri004233.
Eash, D.A., 2003, Main-channel slopes of selected streams in Iowa for estimation of flood-frequency discharges: U.S. Geological Survey Water-Resources Investigations Report 03-4120, 215 p., accessed July 23, 2008, at http://pubs. er.usgs.gov/usgspubs/wri/wri034120.

Hillaker, H.J., 2008, Iowa climate review: Des Moines, Iowa, Iowa Department of Agriculture and Land Stewardship, v. 21, no. $12-$-v. 22, nos.1-6, variously paginated.

Hydrologic Engineering Center, 2002, Regulated frequency curve and pool elevation frequency estimates for the Des Moines and Iowa River Basins, Iowa: Davis, Calif., prepared for the Rock Island District U.S. Army Corps of Engineers, January 2002.

Interagency Advisory Committee on Water Data, 1982, Guidelines for determining flood flow frequency, Bulletin 17-B of the Hydrology Subcommittee: Reston, Va., U.S. Geological Survey, Office of Water Data Coordination, 183 p.. (Also available at http://water.usgs.gov/osw/bulletin17b/dl_flow. $p d f$.

National Climatic Data Center, 2008, Climate of 2008-Midwestern U.S. flood overview: National Climatic Data Center database, accessed July 23, 2008, at http://www.ncdc.noaa. gov/oa/climate/research/2008/flood08.html.

National Weather Service, 2009, Precipitation analysis: National Weather Service database, accessed September 30, 2009, at http://www.srh.noaa.gov/rfcshare/precip_analysis_new.php/.

Rantz, S.E., and others, 1982, Measurement and computation of streamflow-Volume 1, Measurement of stage and discharge, and volume 2, Computation of discharge: U.S. Geological Survey Water-Supply Paper 2175, 631 p.

Sherwood, J.M., Ebner, A.E., Koltun, G.F., and Astifan, B.M., 2007, Flood of June 22-24, 2006, in north-central Ohio, with emphasis on the Cuyahoga River near Independence: U.S. Geological Survey Scientific Investigations Report 2007-5161, 18 p., accessed July 23, 2008, at http://pubs. er.usgs.gov/sir/2007/5161/.

Subcommittee on Hydrology, 2008, Bulletin 17-B guidelines for determining flood frequency, frequently asked questions: Water Information Coordination Program, Advisory Committee on Water Information, Hydrologic Frequency Analysis Work Group, accessed September 4, 2008, http:// acwi.gov/hydrology/Frequency/B17bFAQ.html.

U.S. Army Corps of Engineers, 2009, Iowa River regulated flow study, final report: Rock Island District, October 2009, $78 \mathrm{p}$. 
Publishing support provided by:

Rolla Publishing Service Center

For more information concerning this publication, contact: Director, USGS lowa Water Science Center

P.O. Box 1230

lowa City, IA 52244

(319) 337-4191

Or visit the lowa Water Science Center Web site at:

http://ia.water.usgs.gov 


